\title{
Transfer of Actinoplanes armeniacus Kalakoutskii and Kusnetsov to Streptomyces: Streptomyces armeniacus (Kalakoutskii and Kusnetsov) comb. nov.
}

\author{
E. M. H. WELLINGTON AND S. T. WILLIAMS \\ Department of Botany, University of Liverpool, Liverpool L69 3BX, United Kingdom
}

\begin{abstract}
A study was made of the morphology, cell wall chemotype, and phage susceptibility of Actinoplanes armeniacus ATCC 15676, the type strain of the species (Kalakoutskii and Kusnetsov, Mikrobiologiya 33:553-560, 1964). The spore chains produced by $A$. armeniacus on its aerial mycelium are similar to those typical of streptomycetes. No spore vesicles ("sporangia") were observed. Whole-cell hydrolysates contained LL-diaminopimelic acid. Phage activity spectra showed extensive cross-reactions between streptomycetes and $A$. armeniacus ATCC 15676, whereas a phage propagated on this strain lysed a range of Streptomyces species. On the basis of these characteristics, the transfer of $A$. armeniacus Kalakoutskii and Kusnetsov to the genus Streptomyces is proposed as Streptomyces armeniacus (Kalakoutskii and Kusnetsov) comb. nov. The type strain of this taxon is ATCC 15676. An amended description of this species is given.
\end{abstract}

Kalakoutskii and Kusnetsov (6) described a new species of Actinoplanes, Actinoplanes ar. meniacus, which was characterized by the production of a well-developed aerial mycelium bearing spiral spore chains and "sporangia" containing motile zoospores. The formation of flagellated spores in spore vesicles is a feature of Actinoplanes spp. $(3,4)$. Production of single spore chains on the aerial mycelium has not been reported for any of the other eight species included in the genus Actinoplanes (10-13), although Willoughby (21) reported a conidial actinoplanete which produced tufts of conidiospores similar to the contents of the vesicles but lacking an inflated vesicular sheath. Actinoplanes species have a wall of chemotype II, containing meso-diaminopimelic acid (mesoDAP) with the sugars xylose and arabinose (8). Actinoplanes armeniacus was included in the Approved Lists of Bacterial Names (18) and in a review of the genus Actinoplanes (12).

During our studies on actinophage host ranges, $A$. armeniacus was found to be susceptible to a wide range of phages active on Streptomyces species. Among several hundred phagehost cross-reactions (Wellington and Williams, in K. P. Schaal and G. Pulverer, ed., Actinomycetes, in press), this was the only example of phage apparently cross-infecting members of different cell wall chemotypes sensu Lechevalier and Lechevalier (9). This prompted a taxonomic study of $A$. armeniacus, in which it was revealed that this species is a member of the genus Streptomyces. The results also demonstrate how selected phages may be used as an aid in the recognition of genera of the order Actinomycetales.

\section{MATERIALS AND METHODS}

Bacterial strains. Actinoplanes armeniacus ATCC 15676 (= 26:A-31 = RIA 807) was obtained from the Kaken Chemical Co. Culture Collection, Tokyo, Japan, as KCC A-0070 and from the National Collection of Industrial Bacteria, Aberdeen, Scotland, as NCIB 10179. We compared the two strains with respect to their cultural and morphological characters and found them to be identical in these respects. Details of the other species studied are given in Tables 1 and 2.

Morphology. The morphology and pigmentation of Actinoplanes armeniacus were examined on chitin medium (5), nutrient agar (Oxoid), oatmeal agar, and ISP medium no. 4 (17). Cultures were examined after 3 weeks of incubation at $25^{\circ} \mathrm{C}$. Colonization of pollen grains in sterile deionized water inoculated with $A$. armeniacus ATCC 15676 was investigated after 4 weeks of incubation at $25^{\circ} \mathrm{C}$. Examinations were made by using light and scanning electron microscopy. For scanning electron microscopy, growth was examined on glass cover slips (20) inserted into chitin and oatmeal agar media in plates. Growth on cover slips was dehydrated in formaldehyde vapor for $24 \mathrm{~h}$ and then mounted onto metal specimen stubs with Durofix adhesive. Specimens were coated under vacuum with a thin film (approximately $30 \mathrm{~nm}$ ) of gold-palladium. Observations were made with a Stereoscan electron microscope (Cambridge Scientific Instruments, Ltd.), operating at $20 \mathrm{kV}$, with a $200-\mu \mathrm{m}$ aperture.

The presence of spore vesicles was also investigated by transferring portions of agar with growth to petri dishes containing sterile deionized water and incubating for a further 2 weeks at $25^{\circ} \mathrm{C}$.

Cell wall analysis. Cell wall analysis was carried 
TABLE 1. Streptomyces species ${ }^{\alpha}$ included in phage cross-infection experiments

\begin{tabular}{|c|c|c|}
\hline \multirow{4}{*}{\begin{tabular}{l}
\multicolumn{1}{c}{$\begin{array}{c}\text { Streptomyces } \\
\text { species }\end{array}$} \\
S. almquistii . . . \\
S. arabicus . . . \\
S. aureofaciens \\
${ }^{\alpha}$
\end{tabular}} & \multicolumn{2}{|c|}{$\begin{array}{l}\text { Strain designation } \\
\text { and source }\end{array}$} \\
\hline & ISP 5447 & ATCC 618 \\
\hline & ISP 5252 & ATCC 23881 \\
\hline & LU A196 & \\
\hline S. aureus ${ }^{c} \ldots \ldots$ & ISP 5055 & CUB 110 \\
\hline S. baciilaris & ISP 5598 & ATCC 15855 \\
\hline S. bicolor ${ }^{c}$ & ISP 5140 & ATCC 23614 \\
\hline S. caesius ${ }^{a, c}$ & ISP 5419 & ATCC 19828 \\
\hline S. cellostaticus ${ }^{a}$ & ISP 5189 & ATCC 23894 \\
\hline S. chartreusis ${ }^{a}$ & ISP 5085 & ATCC 14922 \\
\hline S. chryseus ... & ISP 5420 & ATCC 19829 \\
\hline S. coelicolor ${ }^{\alpha}$ & DSM 40683 & \\
\hline S. cretaceus $^{a_{1, c}}$ & ISP 5561 & ATCC 3005 \\
\hline S. endus ..... & ISP 5187 & ATCC 23904 \\
\hline S. fasciculatus ${ }^{c}$ & ISP 5054 & ATCC 19751 \\
\hline S. filipinensis & ISP 5112 & ATCC 23905 \\
\hline S. griseoflavus & ISP 5456 & ATCC 25456 \\
\hline S. kurssanovii ${ }^{a}$ & ISP 5162 & ATCC 15824 \\
\hline S. lavendulocolor & ISP 5216 & ATCC 15871 \\
\hline S. lucensis . . . . . & ISP 5317 & ATCC 17804 \\
\hline S. luridus ${ }^{a} \ldots$ & ISP 5081 & ATCC 19782 \\
\hline S. olivoviridis & ISP 5211 & A'TCC 15882 \\
\hline S. pallidus ${ }^{c}$.. & ISP 5531 & ATCC 27457 \\
\hline S. pilosus & ISP 5097 & ATCC 19797 \\
\hline S. platensis & ISP 5041 & ATCC 23948 \\
\hline S. prasinus ${ }^{a} \ldots$ & ISP 5099 & ATCC 19800 \\
\hline Streptomyces sp. ${ }^{a}$ & LU 253 & \\
\hline Streptomyces sp. ${ }^{a}$ & LU 135 & \\
\hline Streptomyces sp. ${ }^{a}$ & LU 049 & \\
\hline Streptomyces sp. & LU F50 & \\
\hline Streptomyces sp. ${ }^{a}$ & LU 422 & \\
\hline Streptomyces sp. ${ }^{a}$ & LU M7 & \\
\hline S. subrutilus ${ }^{a} \ldots$ & ISP 5445 & ATCC 27467 \\
\hline S. thermotolerans ${ }^{a, c}$ & ISP 5227 & ATCC 11416 \\
\hline S. venezuelae . . . . & ISP 5230 & ATCC 10712 \\
\hline S. violarus ${ }^{c}$ & ISP 5205 & ATCC 25516 \\
\hline
\end{tabular}

${ }^{a}$ Phage propagation hosts.

${ }^{b}$ ISP, International Streptomyces project type strain; ATCC, American Type Culture Collection, Rockville, Md. LU, Culture Collection, Botany Department, University of Liverpool, England; CUB, Actinomycete Culture Collection, Postgraduate School of Studies in Biological Sciences, University of Bradford, England; DSM, German Collection of Microorganisms, Teilsammlung Darmstadt, Darmstadt, Germany. (18).

' Names are not on the Approved Lists of Bacterial Names

TABLE 2. Phage cross-reactions between Actinoplanes armeniacus ATCC 15676, Streptomyces species, and Amorphosporangium auranticolor ATCC 15330.

\begin{tabular}{lcccc}
\hline & & \multicolumn{2}{c}{ Test strains (\% of strains showing lytic reactions) } \\
\cline { 3 - 5 } \multicolumn{1}{c}{ Propagation host } & $\begin{array}{c}\text { No. of } \\
\text { phages }\end{array}$ & $\begin{array}{c}\text { Streptomyces } \\
\text { species } \\
\text { (22 strains) }\end{array}$ & $\begin{array}{c}\text { Actinoplanes } \\
\text { armeniacus } \\
\text { ATCC 15676 }\end{array}$ & $\begin{array}{c}\text { Amorphos- } \\
\text { porangium } \\
\text { auranticolor } \\
\text { ATCC 15330 }\end{array}$ \\
\hline $\begin{array}{l}\text { Streptomycetes } \\
\text { Actinoplanes } \\
\begin{array}{l}\text { armeniacus } \\
\text { ATCC 15676 }\end{array}\end{array}$ & 17 & 58.8 & 35.3 & 0 \\
$\begin{array}{l}\text { Amorphosporangium } \\
\text { auranticolor } \\
\text { ATCC 15330 }\end{array}$ & 1 & 47.6 & 100 & 0 \\
\hline
\end{tabular}

out on Actinoplanes armeniacus ATCC 15676. Wholecell hydrolysates were analyzed for the presence of the isomers of DAP by the method of Rhuland et al. (16). Paper chromatograms were developed for $48 \mathrm{~h}$ by descending chromatography with the solvent system methanol-distilled water-concentrated $\mathrm{HCl}$-pyridine $(80: 11.5: 2.5: 10)$. Standards of the two isomers mesoDAP and LL-DAP were run alongside the extract of Actinoplanes armeniacus.

Phage activity spectra. Phages virulent for $A$. armeniacus ATCC 15676, Amorphosporangium auranticolor ATCC 15330, and Streptomyces species were isolated from natural habitats by a specific enrichment technique modified from that of Bradley et al. (2). Single-plaque isolations were made and were used to prepare high-titer phage lysates by the confluent plate lysate method. All phages were propagated on their isolation hosts. Lysates contained $10^{7}$ to $10^{10}$ plaque-forming units per ml. Phages were maintained at $4^{\circ} \mathrm{C}$ in the peptone-yeast extract broth of Bradley et al. (2).

Phage lysates were sterilized by membrane filtration in which $13-\mathrm{mm}$ Millipore filters $(0.45-\mu \mathrm{m}$ pore size) were used in Swinnex filter units (Millipore Corp., Bedford, Mass.). Filter units were sterilized by autoclaving at $121^{\circ} \mathrm{C}$ for $15 \mathrm{~min}$.

All phage-host cross-reactions were carried out with double-layer plates which contained peptone-yeast extract agar (Difco; $1.2 \%$ [wt/vol]) as a base layer with a host-seeded soft agar $(0.7 \%$ [wt/vol] $)$ overlay. Phage lysates of two different dilutions were spotted $(0.01-\mathrm{ml}$ drop) onto double-layer plates; one dilution gave a clear spot on the propagation host, and the other gave single plaques. Propagation hosts were included in all cross-infection experiments to ensure that appropriate dilutions were plated. Phage $\mathrm{PhJ} 70$, active on $A$. armeniacus ATCC 15676, was tested against streptomycetes and Amorphosporangium auranticolor ATCC 15330, representing cell wall chemotypes I and II, respectively. The reciprocal crosses were made by testing phages virulent for Streptomyces species and Amorphosporangium auranticolor on Actinoplanes armeniacus. A total of 35 Streptomyces strains were included (Table 1); these represented a range of species falling into different clusters as defined in a previous numerical taxonomy study (S. T. Williams, E. M. H. Wellington, M. Goodfellow, G. Alderson, M. J.

\footnotetext{
${ }^{a}$ See Table 2 for strains used.
} 
Sackin, and P. H. A. Sneath, in K. P. Schaal and G. Pulverer, ed., Actinomycetes, in press).

\section{RESULTS AND DISCUSSION}

The morphological and cultural characteristics of Actinoplanes armeniacus are summarized in Table 3. Aerial mycelium was produced on all culture media where growth occurred. Examination by scanning electron microscopy confirmed the presence of long spiral spore chains on the aerial mycelium (Fig. 1 and 2). Kalakoutskii and Kusnetsov (6) reported the presence of spiral sporangia, with usually two to three spiral turns, in which the conidiospores formed. In the present study, only single spore chains were observed; these were enveloped by a spore sheath. Tufts of spore chains lacking an enveloping spore sheath, as reported by Willoughby (21) and Couch (4) for other Actinoplanes species, were not observed.
The original description of A. armeniacus (6) also included observations on sporangia, formation of which was not associated with development of the aerial mycelium. Such sporangia contained motile zoospores. Under the culture conditions employed here, no such structures were observed. Additional evidence suggesting that $A$. armeniacus ATCC 15676, the type species, and, hence, the species, is wrongly classified in Actinoplanes was indicated by the fact that whole-cell hydrolysates contained only LL-DAP. A similar conclusion was reached by Kusnetsov and Rodionova (7). All other Actinoplanes species analyzed to date contain meso-DAP $(1,10$, $11,19)$.

The phage activity spectra (Table 2 ) showed that $A$. armeniacus was susceptible to over onethird of the phages virulent for streptomycetes, whereas almost one-half of the streptomycetes tested were lysed by the phage PHJ70, which

TABLE 3. Cultural and morphological characteristics of Actinoplanes armeniacus on various media

\begin{tabular}{|c|c|c|c|c|}
\hline Medium & $\begin{array}{c}\text { Aerial } \\
\text { mycelium }\end{array}$ & $\begin{array}{l}\text { Substrate } \\
\text { mycelium }\end{array}$ & Sporangia & Spores \\
\hline Chitin & White, powdery & Cream, stable & None & $\begin{array}{l}\text { Long spiral chains } \\
\text { (smooth surface) }\end{array}$ \\
\hline $\begin{array}{l}\text { Nutrient agar } \\
\text { (Oxoid) }\end{array}$ & White, sparse & $\begin{array}{l}\text { Cream to brown, } \\
\text { stable }\end{array}$ & None & Spiral chains \\
\hline Oatmeal agar & White, powdery & Cream, stable & None & $\begin{array}{l}\text { Long spiral chains } \\
\text { (smooth surface) }\end{array}$ \\
\hline ISP no. 4 & White, powdery & Cream, stable & None & Long spiral chains \\
\hline Pollen grains & No growth & No growth & None & No growth \\
\hline
\end{tabular}

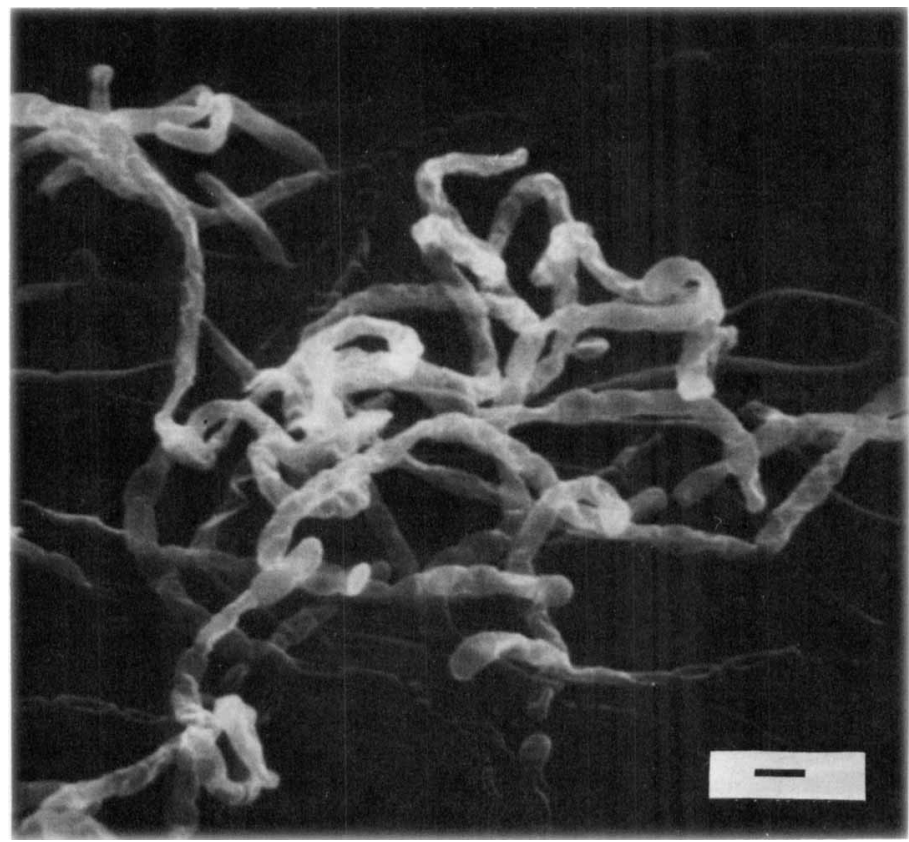

Fig. 1. Spiral spore chains on the aerial mycelium of Actinoplanes armeniacus. Bar, $1.0 \mu m$. 


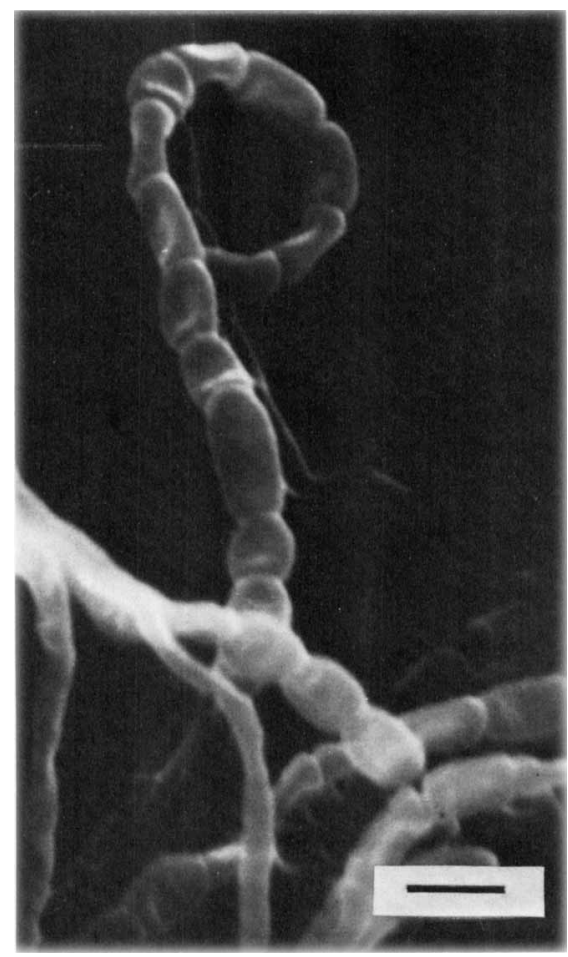

Fig. 2. Hooked spore chain of Actinoplanes armeniacus consisting of spores with a smooth surface. Bar, $1.0 \mu \mathrm{m}$.

was propagated on A. armeniacus. Amorphosporangium auranticolor, which shares a chemotype II cell wall with Actinoplanes spp. (8), showed no phage cross-reaction with $A$. armeniacus or with any streptomycete. Previous results on phage activity spectra have shown a marked correlation between phage host ranges and cell wall chemotype (14, Wellington and Williams, in press). Thus, $A$. armeniacus ATCC 15676 proved to be the only test strain which had a supposed cell wall chemotype other than I and which was lysed by Streptomyces phages. The cell wall analyses of $A$. armeniacus ATCC 15676 revealed a chemotype I cell wall, which explains its marked cross-reactions with phage from other genera with a cell wall of chemotype I. Actinoplanetes sensu stricto were not lysed by phages virulent for members of cell wall chemotype I in the host-range study of Prauser and Falta (15). Bradley et al. (2) found the phages active on actinoplanetes to be genus specific.

Actinoplanes armeniacus ATCC 15676 produced a morphology typical of many streptomycetes; long, spiral spore chains were enveloped in an unornamented spore sheath borne on the aerial mycelium, and the substrate mycelium was stable. The presence of LL-DAP in whole-cell hydrolysates is also a characteristic feature of the genus Streptomyces, and its presence in A. armeniacus confirms that this species is misclassified in Actinoplanes. It is therefore proposed that, on the basis of morphology, cell wall composition, and phage host-range studies, A. armeniacus be transferred to the genus Streptomyces as follows: Streptomyces armeniacus (Kalakoutskii and Kusnetsov) comb. nov. (Basonym: Actinoplanes armeniacus Kalakoutskii and Kusnetsov 1964).

Description of species. Three-week-old cultures showed white aerial mycelia and development of spiral spore chains on chitin medium, nutrient agar, oatmeal agar, and ISP medium no. 4. On all media, the substrate mycelium was stable and cream-colored to brown. No distinctive pigments were produced in the substrate mycelium or in the medium. Whole-cell hydrolysates contained LL-DAP characteristic of cell wall chemotype I. Actinoplanes armeniacus was susceptible to six phages propagated on Streptomyces species. A phage propagated on $A$. armeniacus was also virulent on Streptomyces species.

According to the original description of $A$. armeniacus (6) milk is not coagulated or peptonized, gelatin is liquefied, and nitrate is not reduced. The following carbon sources were utilized for growth: L-rhamnose, sorbitol, galactose, D-fructose, D-arabinose, trehalose, cellobiose, aesculin, glycerin, and inulin. Growth was weak on glucose, sucrose, lactose, maltose, D-raffinose, sorbose, xylose, salicin, and dulcitol. No growth occurred on mannitol. Starch was hydrolyzed. The organism was susceptible to penicillin, streptomycin, chlortetracycline, erythromycin, and polymyxin and was resistant to kanamycin and neomycin.

\section{ACKNOWLEDGMENTS}

This work was supported by research grant G/RA 0403.9 provided by the Science Research Council of Great Britain.

We thank H. R. Perkins and G. J. Smith for carrying out the cell wall analyses.

\section{REPRINT REQUESTS}

Address reprint requests to: Dr. S. T. Williams, Department of Botany, University of Liverpool, P.O. Box 147, Liverpool L69 3BX, United Kingdom.

\section{LITERATURE CITED}

1. Becker, B., M. P. Lechevalier, and H. A. Lechevalier. 1965. Chemical composition of cell-wall preparations from strains of various form-genera of aerobic actinomycetes. Appl. Microbiol. 13:235-243.

2. Bradley, S. G., D. L. Anderson, and L. A. Jones. 1961. Phylogeny of actinomycetes as revealed by susceptibility to actinophage. Dev. Ind. Microbiol. 2:223-237.

3. Couch, J. N. 1950. Actinoplanes, new genus of the Actinomycetales. J. Elisha Mitchell Sci. Soc. 66:87-92.

4. Couch, J. N. 1963. Some new genera and species of the 
Actinoplanaceae. J. Elisha Mitchell Sci. Soc. 79:53-70.

5. Hsu, S. C., and J. L. Lockwood. 1975. Powdered chitin agar as a selective medium for enumeration of actinomycetes in water and soil. Appl. Microbiol. 29:422-426.

6. Kalakoutskii, L. V., and V. D. Kusnetsov. 1964. A new species of the genus Actinoplanes Couch. Mikrobiologiya 33:553-560.

7. Kusnetsov, V. D., and E. G. Rodionova. 1974. Study on composition of diaminopimelic acids of cell walls of antibiotic-producing actinomycetes and their proactinomycete-like variants. Antibiotiki 19:131-135.

8. Lechevalier, M. P., and H. A. Lechevalier. 1970. Composition of whole-cell hydrolysates as a criterion in the classification of aerobic actinomycetes, p. 311-316. In H. Prauser (ed.), The Actinomycetales. Gustav Fischer Verlag, Jena.

9. Lechevalier, M.P., and H. A. Lechevalier. 1970. Chemical composition as a criterion in the classification of aerobic actinomycetes. Int. J. Syst. Bacteriol. 20:435443.

10. Lechevalier, M. P., and H. A. Lechevalier. 1975. Actinoplanete with cylindrical sporangia, Actinoplanes rectilineatus sp. nov. Int. J. Syst. Bacteriol. 25:371-376.

11. Palleroni, N. J. 1979. New species of the genus Actinoplanes, Actinoplanes ferrugineus. Int. J. Syst. Bacteriol. 29:51-55.

12. Parenti, F., and C. Coronelli. 1979. Members of the genus Actinoplanes and their antibiotics. Annu. Rev. Microbiol. 33:389-411.
13. Parenti, F., H. Pagani, and G. Beretta. 1975. Lipiarmycin, a new antibiotic from Actinoplanes. I. Description of the producer strain and fermentation studies $\mathrm{J}$. Antibiot. 28:247-252.

14. Prauser, H. 1976. Host-phage relationships in nocardioform organisms, p. 266-284. In M. Goodfellow, G. H. Brownell, and J. A. Serrano (ed.), The biology of the Nocardiae. Academic Press, Inc., New York.

15. Prauser, H., and R. Falta. 1968. Phagensensibilität, Zellwandzusammensetzung und Taxonomie von Actinomyceten. Z. Allg. Mikrobiol. 8:39-46.

16. Rhuland, L. E., E. Work, R. F. Denman, and D. S. Hoare. 1955. The behavior of the isomers of $\alpha, E$ diaminopimelic acid on paper chromatograms. J. Am. Chem. Soc. 77:4844-4846.

17. Shirling, E. B., and D. Gottlieb. 1966. Methods for characterization of Streptomyces species. Int. J. Syst. Bacteriol. 16:313-340.

18. Skerman, V. B. D., MeGowan, V., and Sneath, P. H. A. 1980. Approved lists of bacterial names. Int. J. Syst. Bacteriol. 30:225-420.

19. Szaniszlo, P. J., and H. Gooder. 1967. Cell wall composition in relation to the taxonomy of some Actinoplanaceae. J. Bacteriol. 94:2037-2047.

20. Williams, S. T., and F. L. Davies. 1967. Use of a scanning electron microscope for examination of actinomycetes. J. Gen. Microbiol. 48:171-177.

21. Willoughby, L. G. 1966. A conidial Actinoplanes isolate from Blelham Tarn. J. Gen. Microbiol. 44:69-72. 